\title{
Correction to: Supply Chain Resilience
}

\author{
Venkatachalam Anbumozhi, Fukunari Kimura,
} and Shandre Mugan Thangavelu

\section{Correction to: \\ V. Anbumozhi et al. (eds.), Supply Chain Resilience, https://doi.org/10.1007/978-981-15-2870-5}

The original version of the book was inadvertently published with incorrect copyright holder's name on the copyright page of the front matter. The front matter and the book have now been updated with the changes.

The updated version of the book can be found at

https://doi.org/10.1007/978-981-15-2870-5 